\title{
sciendo
}

\section{GENETIC CHARACTERISTICS OF BROOK TROUT Salvelinus fontinalis (MITCHILL, 1848) BROODSTOCKS FROM HATCHERIES IN BOSNIA AND HERZEGOVINA}

\author{
Belma Kalamujić Stroil*, Mia Stanić, Abdurahim Kalajdžić, Naris Pojskić
}

University of Sarajevo-Institute for Genetic Engineering and Biotechnology (INGEB), Zmaja od Bosne 8 Kampus, 71000 Sarajevo, Bosnia and Herzegovina

*Corresponding Author, Email: belma.kalamujic@ingeb.unsa.ba

\section{ARTICLE INFO}

Received: 10 July 2020

Accepted: 18 August 2020

\section{Keywords:}

Inbreeding

Developmental deformities

Microsatellites

Mitochondrial DNA

\section{ABSTRACT}

The most commonly farmed fish species in Bosnia and Herzegovina's aquaculture are from the family Salmonidae, including brook trout Salvelinus fontinalis which is reared both for consumption and stocking purposes. A number of farmers complained about the elevated frequency of anatomical deformities in the smolts and fingerlings of brook trout, decreasing their fitness rate and causing significant financial loss. Since it has been shown that occurrence of deformities is correlated with the low genetic diversity and high inbreeding, this study aimed to assess intra- and interpopulation diversity of Salvelinus fontinalis from different freshwater fish farms in Bosnia and Herzegovina by observing variation in mitochondrial and nuclear genome. Total of 109 samples of brook trout from three hatcheries located at the Neretva River were analyzed for the mitochondrial control region and seven nuclear microsatellite loci. Both PCR-RFLP and sequencing revealed only one haplotype of the control region in all investigated trout. Overall, a low number of genotypes was evident across all the observed loci. Values of genetic diversity and polymorphic information content followed the increase in the number of alleles per locus. In general, values of inbreeding coefficient were generally very high, while the genetic diversity and observed heterozygosity had low rates. The results of our study are congruent with the findings of previous studies in which developmental deformities were concomitant with the low genetic diversity and inbreeding depression. It is, therefore, strongly advised to regularly supplement the broodstock with new, unrelated individuals, as it is of vital importance for sustaining a satisfying level of genetic diversity and preventing inbreeding depression. Additionally, maintaining good management practices regarding the fluctuation of water temperature, exposure to pollution, nutrition, etc., will further contribute to the prevention of this detrimental condition.

Kalamujić Stroil, B., Stanić, M., Kalajdžić, A., Pojskić, N. (2020): Genetic characteristics of brook trout Salvelinus fontinalis (Mitchill, 1848) broodstocks from hatcheries in Bosnia and Herzegovina. Croatian Journal of Fisheries, 78, 183-194. DOI: 10.2478/cjf-2020-0018. 


\section{INTRODUCTION}

Notwithstanding the rich and diverse inland hydrological network, the aquaculture sector in Bosnia and Herzegovina $(B \& H)$ is still underutilized. There are a number of constraints to upgrading the status of the sector in the country: unharmonized laws on fisheries, lack of systematic support in licensing and financing, no coordination across different levels of government, absence of monitoring and supervision in the aquaculture sector, unavailability of training programs in various fields for fish farmers in order to improve and update basic knowledge and technological know-how indispensable to the increase of productivity and efficiency (for detailed overview see FAO, 2015). According to the latest data, around 140 fish species, either continuously or temporarily, inhabit freshwater systems in Bosnia and Herzegovina (Muhamedagic et al., 2008). Some 60 species of the country's ichthyofauna are cultured or have commercial and/or game value (FAO, 2015). The most commonly reared species in $B \& H$ aquaculture are the ones from the family Salmonidae, including brook trout Salvelinus fontinalis (Mitchill, 1848).

The native range of brook trout expands from freshwaters of south-western Alaska to the Sierra Madre Occidental in Mexico, and to the tributaries of the Pacific Ocean in Asia (Behnke, 2002). During the 20th century, due to its high adaptability and fast growth, brook trout has been introduced worldwide, both in natural waterways and as broodstock for farming. Since then, it has become one of the most important species in commercial aquaculture, especially in Europe and Chile. The global production of brook trout reached a total of 814,068 tons in 2013. In Bosnia and Herzegovina, brook trout is reared both for consumption and stocking purposes, but no official data on annual production rate exist. The first record of introduction of $S$. fontinalis into B\&H's River Bioštica predates World War I. Subsequently, the specimens of this species were introduced into some lakes on Zelengora Mountain, as well as into the reservoirs at the Rivers Neretva, Trebišnjica and Vrbas. The finding of $S$. fontinalis population in the River Pištica (Kosoric, 1981) was a unique example of the existence of feral population in our country. In spite of the long-term stocking efforts in the Neretva basin, there is no recent information about the establishment of $S$. fontinalis self-sustaining feral populations in Bosnian-Herzegovinian waters.

During our previous study visits to the fish farms, a number of farmers complained about the elevated frequency of morphological deformities in the smolts and fingerlings of brook trout, decreasing their fitness rate and causing significant financial loss. Reported malformities included vertebral deformity and bent dorsal or caudal fin. Although it is known that developmental deformities in fish can be caused by environmental stress (Silverstone and Hammell, 2002; Sato, 2006; Fjelldal et al., 2012), it has also been shown that occurrence of deformities is correlated with a low genetic diversity and high inbreeding (Morita and Yamamoto, 2000; Shikano et al., 2005). Some studies even demonstrated the heritability of the spinal deformity (Shikano et al., 2005; Sullivan et al., 2007; Chin et al., 2016). In order to test the concomitance of morphological abnormalities and inbreeding depression, the present study aimed to assess intra- and interpopulation diversity of Salvelinus fontinalis from different freshwater fish farms in Bosnia and Herzegovina by observing variation in mitochondrial (mtDNA) and nuclear genome.

\section{MATERIAL AND METHODS}

\section{Sampling}

Total of 77 samples of brook trout from the broodstocks were collected at three hatcheries located at the Neretva River (Fig. 1, Table 1). Analysis also included 32 archival tissue samples of $S$. fontinalis from the Regional Database of Biodiversity (REBIDA) (Kalamujić Stroil et al., 2017).

Table 1. Location, broodstock codes and number of analyzed samples. Numbers and dates in brackets refer to the samples originating from REBIDA database

\begin{tabular}{lcc}
\hline \hline Hatchery/population & $\begin{array}{c}\text { Number of } \\
\text { individuals }\end{array}$ & Time of collection \\
\hline Konjic (KON) & $10(8)$ & Nov 2012 (Apr 2008) \\
Salakovac (SAL) & $9(20)$ & Dec 2012 (Feb 2007) \\
Donja Jablanica (DJA) & $58(4)$ & Jun 2013 (Apr 2008) \\
Total & 109 & \\
\hline
\end{tabular}

\section{DNA isolation}

DNA isolation was performed from the abdominal fin clippings following the salting-out protocol (Miller et al., 1988), optimized for DNA isolation from fin tissue (Durmić-Pašić et al., 2005). Quality and yield of genomic DNA were tested by spectrophotometry and horizontal gel electrophoresis in SB buffer (Brody and Kern, 2005).

\section{Analysis of mtDNA}

Variation in S. fontinalis mtDNA was investigated by PCRRFLP and sequencing analysis of the control region (CR). Universal primers for salmonid fish, 28RIBa (Snoj et al., 2000) and HN20 (Bernatchez and Danzmann, 1993), were used to amplify $1050 \mathrm{bp}$ fragment of mtDNA CR in all 109 samples of brook trout. Amplification reaction (total volume of $25 \mu \mathrm{l}$ ) consisted of $0.2 \mu \mathrm{M}$ of each primer, $0.2 \mu \mathrm{M}$ dNTP, $2.5 \mathrm{mM} \mathrm{MgCl}$ and 1 unit of AmpliTaq Gold $^{\circledR}$ with the corresponding buffer. After initial $3 \mathrm{~min}$ activation at $95^{\circ} \mathrm{C}$, amplification process included 30 cycles with $1 \mathrm{~min}$ at $53^{\circ} \mathrm{C}$ allowed for annealing and 1 min at $72^{\circ} \mathrm{C}$ for elongation, followed by the final $4 \mathrm{~min}$ 


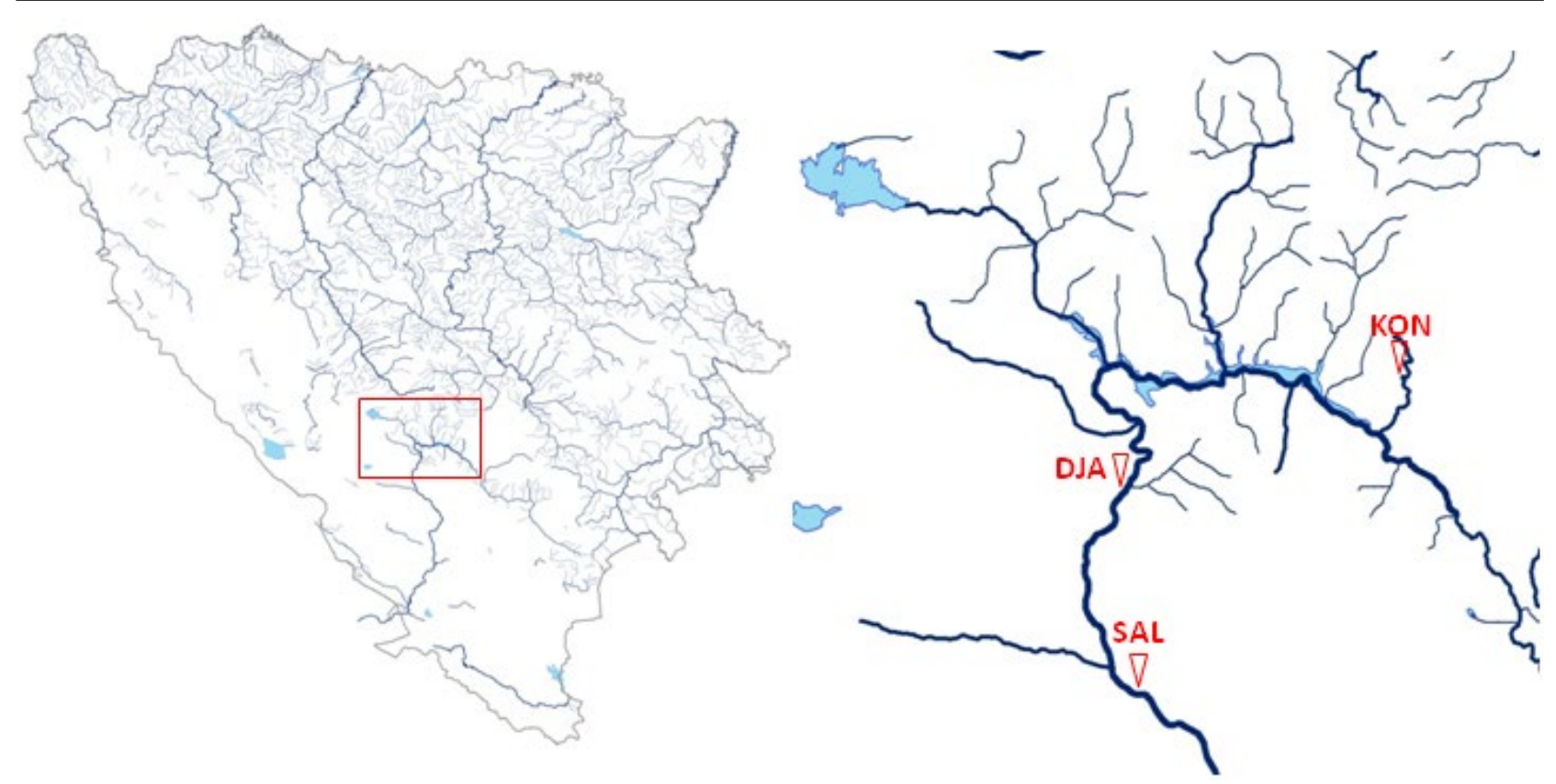

Fig 1. Investigated region (left) with enlarged depiction of hatcheries' positions (right)

elongation at $72^{\circ} \mathrm{C}$. Amplified products were digested using Alul and Mspl enzymes (New England Biolabs), according to the manufacturer's recommendation. Sizing of the generated restriction fragments was done by using DNA 1000 biochip assay (2100 Bioanalyzer, Agilent Technologies). In order to identify the detected haplotypes, Sanger sequencing with forward primer 28RIBa was performed by MACROGEN Europe. Obtained mitochondrial sequences were identified by identity and similarity scores in local databases using the FASTA program (Pearson, 1994) and BLAST network service at NCBI platform (Benson et al., 2003). Sequencing reads were assembled using the sequence editor and checked manually for sequencing errors. Multiple sequence alignment (MSA) was performed against ClustalW ver. 1.6 (Thompson et al., 2011) under default parameters. Subsequently, all sequences were optimized by Jalview 2.9.0b2 (Waterhouse et al., 2009). MSA output was edited using BioEdit v. 5.09 (Hall, 1999). A consensus sequence was deposited in the GenBank database under the accession number KX094562. Haplotype identification was done by aligning the consensus sequence from this study against those available from the database (AF545048-AF545058).

\section{Analysis of microsatellite markers}

Microsatellite markers designed for $S$. fontinalis (Sfo-8, Sfo-12, Sfo-18 and Sfo-23; Angers et al., 1995), Salmo salar (Ssa-85 and Ssa-197; O'Reilly et al., 1996) and Thymallus thymallus (Bfro-4; Snoj et al., 1999) were analyzed. All Sfo microsatellite markers were amplified in single reactions according to Angers et al. (1995), while for Ssa-197 the procedure by Brunner et al. (1998) was followed. For the amplification of Ssa-85 and Bfro-4, reactions consisted of $0.2 \mu \mathrm{M}$ of each primer, $0.2 \mu \mathrm{M}$ dNTP, $1.5 \mathrm{mM} \mathrm{MgCl}_{2}$ and 0.5 u AmpliTaq Gold ${ }^{\circledR}$ with the corresponding buffer. Amplification process included 3 min of initial activation at $94^{\circ} \mathrm{C}$, followed by 33 cycles with denaturation at $94^{\circ} \mathrm{C}$ for $30 \mathrm{sec}$, annealing at $55^{\circ} \mathrm{C}$ for $30 \mathrm{sec}$ and $1 \mathrm{~min}$ at $72^{\circ} \mathrm{C}$ for elongation, ending with $7 \mathrm{~min}$ of final elongation at $72^{\circ} \mathrm{C}$. The forward primer of each primer pair was fluorescently labeled at $5^{\prime}$ end thus genotyping was performed using ABI PRISM 310 Genetic Analyzer (Applied Biosystems ${ }^{\circledR}$ ). Allele scoring was done using GeneMapper ${ }^{\circledR}$ v. 3.2.

\section{Biostatistical data analysis and population-genetic analysis}

Micro-Checker v. 2.2.3. (Van Oosterhout et al., 2004) was used to screen for null alleles in analyzed microsatellite loci. Population genetic parameters and indicators of genetic diversity were obtained using PowerMarker v. 3.25. (Liu and Muse, 2005). Number of effective alleles was calculated as $1 / \Sigma p_{i}{ }^{2}$, where $p_{i}$ represents allele frequency at a given locus. To determine genetic variation among broodstocks, within broodstocks and within individuals, AMOVA analysis was performed within PowerMarker v. 3.25. In order to assess the genetic divergence of investigated broodstocks, the Factorial Correspondence Analysis (FCA), a multivariate analysis based on allele frequencies, was performed within the Genetix 4.05 (Belkhir et al., 1996-2004). For calculating the index of major allele frequency (iMAF), iMAF - R script was used (Pojskić, 2018), which was calculated as IfM $=\left(1 / A_{N}\right) / f M$, where $A_{N}$ is number of detected alleles and $f M$ is major allele frequency at a given locus. This index represents a simple measure of allele frequency distribution and its statistical significance. Result of this index varies from 0 (absence of polymorphism at a given locus) to 1 (all alleles have the same frequency). $P<0.01$ was considered statistically significant (Pojskić, 2018). 


\section{RESULTS}

\section{MtDNA diversity}

All 109 samples of brooktrout displayed the same enzymatic profiles after the digestion of mtDNA CR amplicons with Alul and Mspl enzymes. Digestion with Alul enzyme generated three fragments of approximate sizes 420, 373 and $257 \mathrm{bp}$, while restriction on $\mathrm{Mspl}$ also produced three fragments of 600,250 and $200 \mathrm{bp}$ in size. All 20 selected samples displayed the same nucleotide sequence of the analyzed mitochondrial segment. The alignment of $385 \mathrm{bp}$ of available brook trout D-loop haplotypes from GenBank (AF545048-AF545058) revealed 12 polymorphic sites, distinguishing nine different haplotypes (Table 2). The consensus sequence (KX094562) from this study was congruent with the haplotype 1 (Table 2). The transition/ transversion ratio within the investigated segment was low (2:1, respectively).

\section{Allelic diversity}

Population genetic analysis of microsatellite profiles in this study included specimens of $S$. fontinalis from three broodstocks as well as samples archived in REBIDA, originating from the same populations. Breakdown of the number of alleles per locus for the total analyzed sample and individual broodstocks is given in Tables 3-6. Although no monomorphic loci were found in the total sample, Bfro-4 showed no polymorphism in groups KON and SAL (Tables 4 and 5). Generally, the lowest number of alleles was found in broodstock KON (Table 4) while stock DJA showed the greatest number of alleles per locus (Table 6). The largest number of alleles (8) in the overall sample was detected for $5 f o-23$ with all the observed alleles present in broodstock DJA. In the overall sample, the highest value of major allele frequency (MAF) was observed for locus Bfro-4 (0.9356), while the lowest value was detected for locus $S f o-18(0.3020$, Table 3$)$. In regards to iMAF for DJA broodstock, locus Sfo-12 had the highest value of this measure (0.6110) while Bfro-4 locus had the lowest $(0.2270)$. This measure points out to the fact that the major allele frequency of the $B$ fro- $4(\mathrm{P}=0.0045)$ has a statistically significant higher proportion than expected, assuming equal frequencies of all detected alleles at the given locus $(P<0.01)$. For KON and SAL broodstocks, since Bfro-4 showed no polymorphism, iMAF and its $P$ value could not be calculated. The highest value of iMAF for KON broodstock was found at Sfo-12 locus (0.7080) and the lowest at $S f o-8(0.4040)$. No statistically significantly higher proportion in this broodstock was found. In the overall sample, the highest value of iMAF was found at $\mathrm{Ssa}$ 85 locus (0.6730) and the lowest at Bfro-4 locus (0.2140). This index shows that the major allele frequency of $B$ fro$4(\mathrm{P}=0.0034)$, Sfo-8 $(\mathrm{P}=0.0042)$ and Ssa-197 $(\mathrm{P}=0.0082)$ loci has statistically significantly higher proportion than expected assuming equal frequencies of all the detected alleles at the given loci. For SAL broodstock, the highest value was found at $S s a-85$ locus $(0.8060)$ and the lowest at Ssa-197 (0.2830) locus. As in the case of KON broodstock, no statistically significantly higher proportion was found (Fig. 2).

Overall, a low number of genotypes was evident across all the observed loci. Values of genetic diversity and PIC followed the increase in the number of alleles per locus. The lowest value of genetic diversity was observed at locus Bfro-4 which was understandable considering discernible monomorphism. The greatest value of He was observed at locus Sfo-23. In general, values of inbreeding coefficient were generally very high, while the genetic diversity and observed heterozygosity had low rates (Table 3 ).

Table 2. Substitution profiles of detected haplotypes against the reference sequence AF545048. Haplotype codes correspond to those in GenBank database under the accession numbers AF545048-AF545058, respectively. Polymorphic sites correspond to the nucleotide positions in the reference sequence

\begin{tabular}{|c|c|c|c|c|c|c|c|c|c|c|c|c|}
\hline \multirow{2}{*}{ Haplotype } & \multicolumn{12}{|c|}{ Polymorphic site } \\
\hline & 66 & 82 & 84 & 99 & 122 & 154 & 191 & 222 & 267 & 273 & 284 & 290 \\
\hline $\mathrm{H} 1$ & $\mathrm{G}$ & $C$ & $\mathrm{~T}$ & $A$ & $A$ & $C$ & $\mathrm{~T}$ & A & G & $T$ & C & $C$ \\
\hline $\mathrm{H} 2 / \mathrm{H} 3$ & & & $\mathrm{C}$ & & & & & & & & & \\
\hline $\mathrm{H} 4$ & & & & & & & & $T$ & & & & \\
\hline $\mathrm{H} 5 / \mathrm{H} 6$ & $A$ & & C & & & G & C & & & C & & \\
\hline $\mathrm{H} 7$ & $A$ & & & & & G & C & & $A$ & & & \\
\hline $\mathrm{H} 8$ & A & & & & G & G & $C$ & & $A$ & & & \\
\hline H9 & A & $A$ & & & & G & C & & $A$ & & & \\
\hline $\mathrm{H} 10$ & A & & & & & G & C & & & & & \\
\hline H11 & & & & G & & & C & & & & $\mathrm{T}$ & $A$ \\
\hline
\end{tabular}




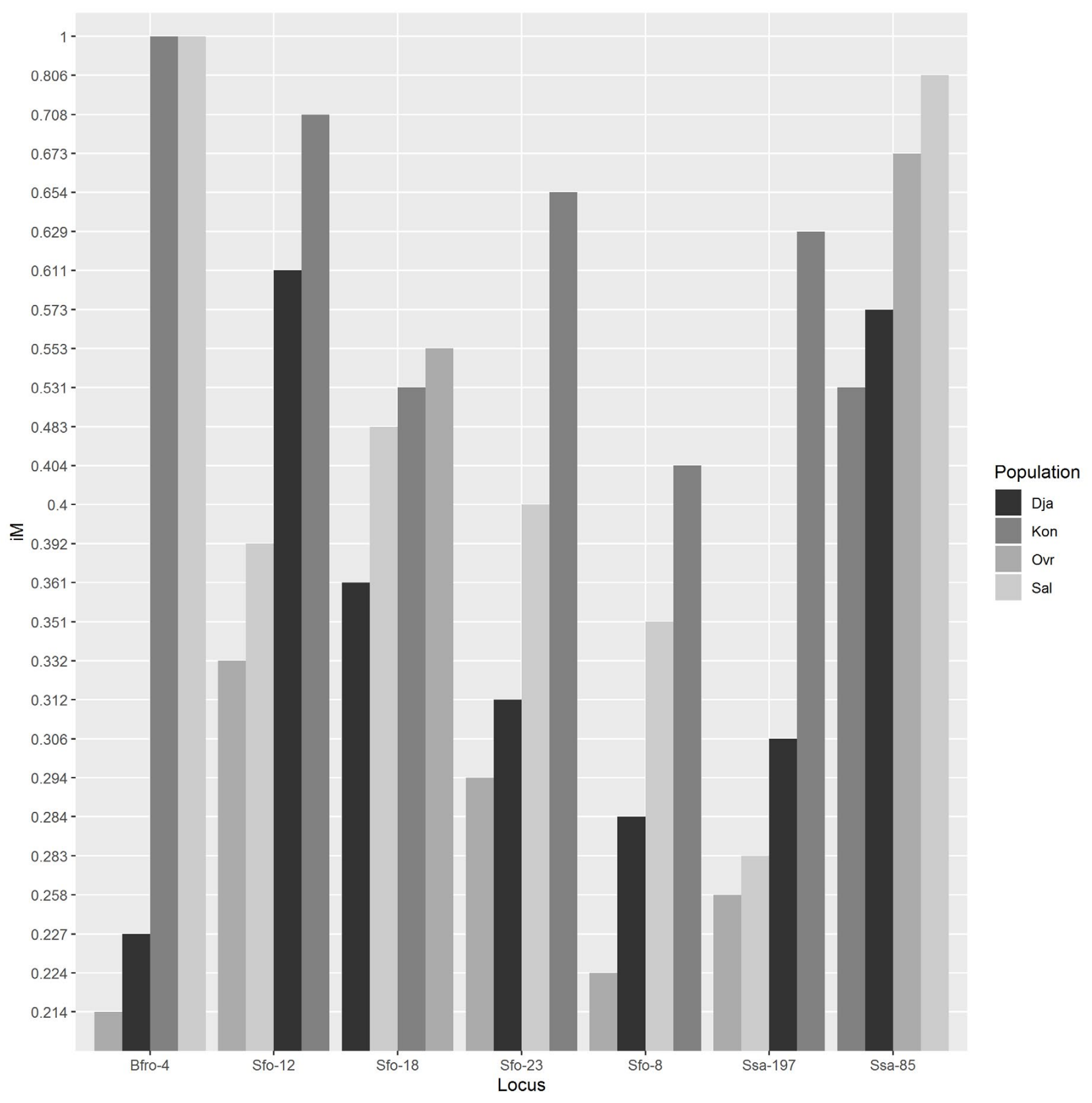

Fig 2. Index of major allele frequencies (iMAF) for seven analyzed loci in three observed broodstocks and overall. DjaDonja Jablanica, Kon - Konjic, Ovr - overall, Sal - Salakovac

Across all loci, the same alleles were the most frequent ones in all broodstocks with the exception of locus Sfo18. Private alleles were detected in both SAL and DJA broodstocks. SAL stock displayed three unique alleles at two loci (Sfo-12 and Sfo-18), while DJA showed 12 private alleles at five loci (Sfo-8, Sfo-12, Sfo-18, Sfo-23 and Bfro4).

Summarized values of inbreeding parameters for each analyzed microsatellite locus are given in Table 3. Inbreeding coefficient among broodstocks $(f)$ was extremely high, except for loci Sfo-8 and Sfo-12. A similar trend was observed for the inbreeding coefficient within the total sample (F). Overall $\theta$ was high (0.1839). Table 7 shows the estimated pairwise Fst values among analyzed hatchery stocks. The greatest level of differentiation was observed between KON and SAL while broodstock DJA showed similar differentiation from the other two stocks. Generally, differentiation between observed broodstocks was noticeable. AMOVA ascertained the level of variation among stocks of $13.1 \%$, which, considering their hatchery origin, makes for a moderate level of variation. The largest variation within observed stocks was estimated in DJA $(39.2 \%)$, while KON broodstock had the lowest variation (8.7\%). 
Table 3. Heterogeneity indicators of the overall sample. $A_{N}-$ Number of detected alleles, $A_{E}-$ Number of effective alleles, $G_{N}$ - Number of detected genotypes, $\mathrm{He}$ - expected heterozygosity, $\mathrm{Ho}$ - observed heterozygosity, PIC - polymorphic information content, $f$-inbreeding factor within population, $\vartheta$ - genetic diversity

\begin{tabular}{lccccccccc}
\hline \hline Locus & MAF & $\mathrm{A}_{\mathrm{N}}$ & $\mathrm{A}_{\mathrm{E}}$ & $\mathrm{G}_{\mathrm{N}}$ & $\mathrm{He}$ & Ho & PIC & $f$ & $\vartheta$ \\
\hline Sfo-8 & 0.8911 & 5 & 1.252 & 5 & 0.2014 & 0.2079 & 0.1942 & -0.0274 & 0.0188 \\
Sfo-12 & 0.4307 & 7 & 2.997 & 13 & 0.6663 & 0.6337 & 0.6045 & 0.0540 & 0.0877 \\
Sfo-18 & 0.3020 & 6 & 4.065 & 9 & 0.7540 & 0.0693 & 0.7119 & 0.9089 & 0.4262 \\
Sfo-23 & 0.4257 & 8 & 3.185 & 12 & 0.6860 & 0.4356 & 0.6340 & 0.3693 & 0.0284 \\
Ssa-85 & 0.7426 & 2 & 1.619 & 2 & 0.3823 & 0.0000 & 0.3092 & 1.0000 & 0.3777 \\
Ssa-197 & 0.6485 & 6 & 2.2 & 8 & 0.5454 & 0.1188 & 0.5161 & 0.7841 & 0.0356 \\
Bfro-4 & 0.9356 & 5 & 1.14 & 5 & 0.1232 & 0.0297 & 0.1207 & 0.7610 & 0.0337 \\
Average & 0.6252 & 5.5714 & 1.922 & 7.7143 & 0.4798 & 0.2136 & 0.4415 & 0.5583 & 0.1839 \\
\hline \hline
\end{tabular}

Table 4. Heterogeneity indicators of KON broodstock. $A_{N}-$ Number of detected alleles, $A_{E}-$ Number of effective alleles, $G_{N}-$ Number of detected genotypes, He - expected heterozygosity, Ho - observed heterozygosity, PIC - polymorphic information content, $f$-inbreeding factor within population; ${ }^{*} \mathrm{NaN}$ - no numerical value exists. ( $\mathrm{NaN}$ is due to the lack of polymorphism at the locus.)

\begin{tabular}{lcccccccc}
\hline \hline Locus & MAF & $\mathrm{A}_{\mathrm{N}}$ & $\mathrm{A}_{\mathrm{E}}$ & $\mathbf{G}_{\mathrm{N}}$ & He & Ho & PIC & $f$ \\
\hline Sfo-8 & 0.8235 & 3 & 1.438 & 3 & 0.3045 & 0.3529 & 0.2809 & 0.0000 \\
Sfo-12 & 0.4706 & 3 & 2.24 & 4 & 0.5536 & 0.4706 & 0.4525 & 0.1795 \\
Sfo-18 & 0.9412 & 2 & 1.124 & 2 & 0.1107 & 0.0000 & 0.1046 & 1.0000 \\
Sfo-23 & 0.3824 & 4 & 3.568 & 7 & 0.7197 & 0.4118 & 0.6697 & 0.4523 \\
Ssa-85 & 0.9412 & 2 & 1.124 & 2 & 0.1107 & 0.0000 & 0.1046 & 1.0000 \\
Ssa-197 & 0.5294 & 3 & 2.603 & 4 & 0.6159 & 0.1176 & 0.5546 & 0.8192 \\
Bfro-4 & 1.0000 & 1 & 1 & 1 & 0.0000 & 0.0000 & 0.0000 & $* \mathrm{NaN}$ \\
Average & 0.7269 & 2.5714 & 1.527 & 3.2857 & 0.3450 & 0.1933 & 0.3096 & 0.4639 \\
\hline \hline
\end{tabular}

Table 5. Heterogeneity indicators of SAL broodstock. $A_{N}-$ Number of detected alleles, $A^{E}-$ Number of effective alleles, $G_{N}-$ Number of detected genotypes, He - expected heterozygosity, Ho - observed heterozygosity, PIC - polymorphic information content, $f$-inbreeding factor within population; ${ }^{*} \mathrm{NaN}-$ no numerical value exists. ( $\mathrm{NaN}$ is due to the lack of polymorphism at the locus.)

\begin{tabular}{lcccccccc}
\hline \hline Locus & $\mathrm{MAF}$ & $\mathrm{A}_{\mathrm{N}}$ & $\mathrm{A}_{\mathrm{E}}$ & $\mathrm{G}_{\mathrm{N}}$ & He & Ho & PIC & $f$ \\
\hline Sfo-8 & 0.9483 & 3 & 1.11 & 3 & 0.0993 & 0.1034 & 0.0966 & 0.0000 \\
Sfo-12 & 0.6379 & 4 & 1.981 & 6 & 0.4952 & 0.5172 & 0.4154 & 0.0000 \\
Sfo-18 & 0.5172 & 4 & 2.511 & 5 & 0.6017 & 0.2069 & 0.5288 & 0.6660 \\
Sfo-23 & 0.5000 & 5 & 2.649 & 8 & 0.6225 & 0.4483 & 0.5566 & 0.2959 \\
Ssa-85 & 0.6207 & 2 & 1.89 & 2 & 0.4709 & 0.0000 & 0.3600 & 1.0000 \\
Ssa-197 & 0.7069 & 5 & 1.853 & 6 & 0.4602 & 0.3448 & 0.4198 & 0.2670 \\
Bfro-4 & 1.0000 & 1 & 1 & 1 & 0.0000 & 0.0000 & 0.0000 & $* \mathrm{NaN}$ \\
Average & 0.7044 & 3.4285 & 1.647 & 4.4286 & 0.3928 & 0.2315 & 0.3396 & 0.4251 \\
\hline \hline
\end{tabular}


Table 6. Heterogeneity indicators of DJA broodstock. $A_{N}-$ Number of detected alleles, $A_{E}-$ Number of effective alleles, $G_{N}-$ Number of detected genotypes, $\mathrm{He}$ - expected heterozygosity, $\mathrm{Ho}$ - observed heterozygosity, PIC - polymorphic information content, $f$-inbreeding factor within population

\begin{tabular}{lcccccccc}
\hline \hline Locus & MAF & $\mathbf{A}_{\mathrm{N}}$ & $\mathrm{A}_{\mathrm{E}}$ & $\mathbf{G}_{\mathrm{N}}$ & He & Ho & PIC & $f$ \\
\hline Sfo-8 & 0.8818 & 4 & 1.275 & 4 & 0.2157 & 0.2182 & 0.2053 & 0.0000 \\
Sfo-12 & 0.3273 & 5 & 3.492 & 10 & 0.7136 & 0.7455 & 0.6584 & 0.0000 \\
Sfo-18 & 0.5545 & 5 & 2.435 & 6 & 0.5893 & 0.0182 & 0.5243 & 0.9697 \\
Sfo-23 & 0.4000 & 8 & 3.037 & 12 & 0.6707 & 0.4364 & 0.6136 & 0.3575 \\
Ssa-85 & 0.8727 & 2 & 1.286 & 2 & 0.2221 & 0.0000 & 0.1975 & 1.0000 \\
Ssa-197 & 0.6545 & 5 & 2.126 & 5 & 0.5296 & 0.0000 & 0.4927 & 1.0000 \\
Bfro-4 & 0.8818 & 5 & 1.278 & 5 & 0.2177 & 0.0545 & 0.2103 & 0.7534 \\
Average & 0.6532 & 4.8571 & 1.822 & 6.2857 & 0.4512 & 0.2104 & 0.4146 & 0.5403 \\
\hline \hline
\end{tabular}

Table 7. Pairwise Fst values for all analyzed broodstocks

\begin{tabular}{lccc}
\hline \hline Broodstocks & KON & SAL & DJA \\
\hline KON & 0.0000 & & \\
SAL & 0.2059 & 0.0000 & 0.0000 \\
DJA & 0.1787 & 0.1785 & \\
\hline \hline
\end{tabular}

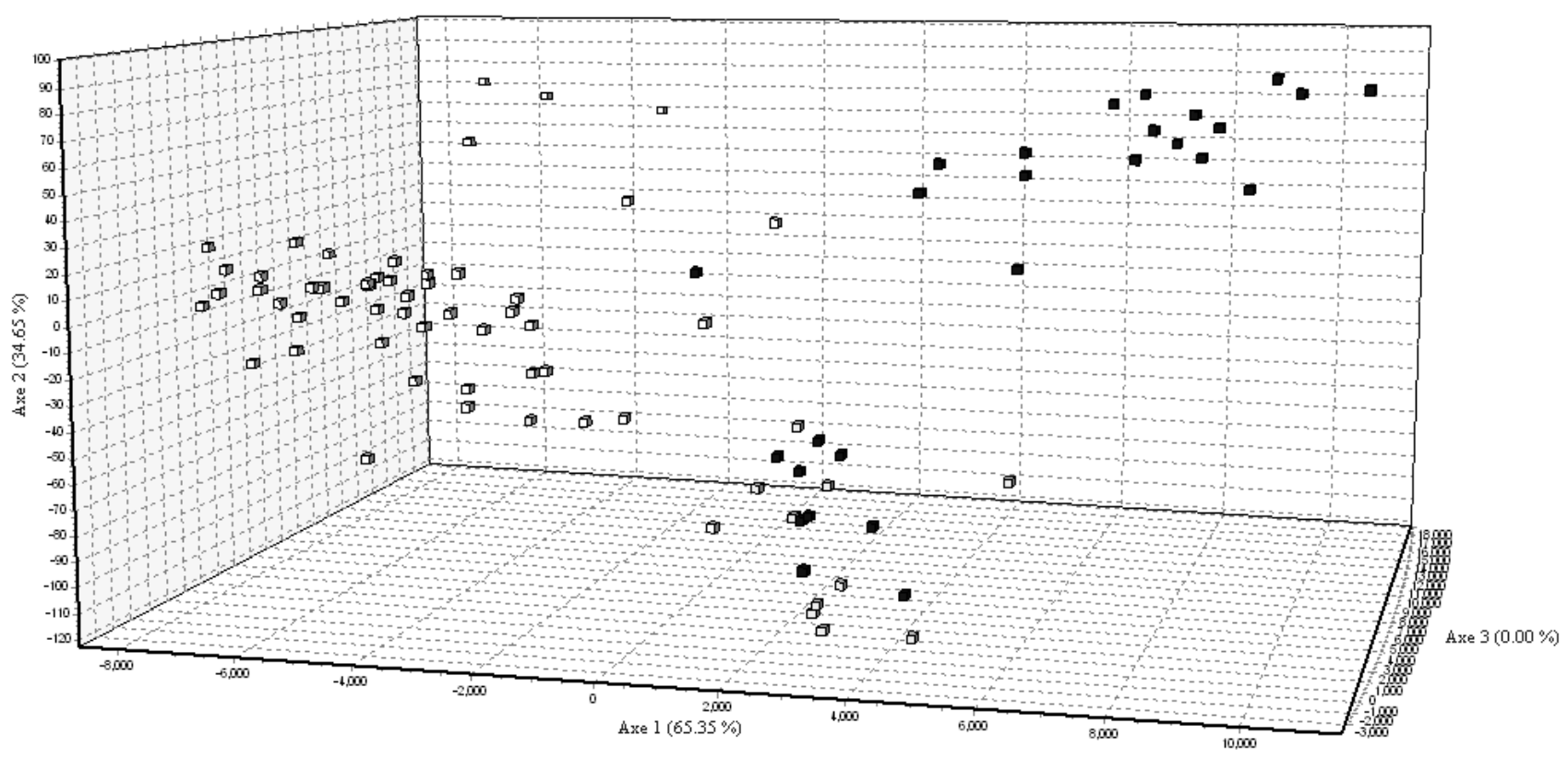

Fig 3. Results of the Factorial Correspondence Analysis (FCA). White blocks - Donja Jablanica (Dja), gray blocks - Konjic (Kon), black blocks - Salakovac (Sal) 
These results are in concordance with the findings of FCA analysis which showed reasonable differentiation of three broodstocks, with only a couple of samples coming close or grouping with other clusters (Fig. 3). The dispersal pattern of samples in FCA clusters representing KON, SAL and DJA agreed with the level of gene diversity in these broodstocks.

\section{DISCUSSION}

Genetic structure of brook trout populations across its native range has been extensively studied utilizing both nuclear and mitochondrial markers. While mtDNA provides invaluable insight into migration and colonization patterns as well as possible interspecies hybridization, neutral nuclear markers such as microsatellites are better indicators of recent events at the population level. Investigations of North American populations of brook trout revealed extensive genetic diversity of this species (Bernatchez and Danzmann, 1993; Beer et al., 2019; Bruce et al., 2019).

However, there are significant differences in genetic structure between hatchery stock and feral populations (Shikano et al., 2008). Hatchery populations frequently undergo a reduction of genetic diversity. Breeding stocks rapidly lose rare alleles that were present in the founding populations (Allendorf, 1986). Also, a short-term bottleneck, which occurs when establishing a broodstock, may affect the process of loss of rare and private alleles, but cannot significantly influence heterozygosity (Nei et al., 1975; Allendorf, 1986). Certain reproduction scenarios and fluctuations in population size may cause a reduction in effective population size $(\mathrm{Ne})$ which in return results in decreased allelic diversity in hatchery stocks (Fopp-Bayat et al., 2010). Inbreeding is an outstanding issue in hatcheries that can lead to a sharp reduction in broodstock fitness and the inability of a population to self-sustain when released into the wild (Ferguson-Castle Douglas, 2006). However, monitoring programs utilizing molecular markers analysis may prevent loss of genetic diversity, especially if applied at the phase of hatchery establishment (Lacy, 1989; Brudford and Wayne, 1993). The focus of the present study was on individuals of brook trout from three broodstocks located in the River Neretva, Bosnia and Herzegovina, reported to have been suffering from increased frequency of morphological malformations in smolts and fingerlings. Such fish have a low survival rate or, due to their appearance, are undesirable for commercial purposes thus causing a significant financial loss for the fish farms. Previous studies established a causal link between the occurrences of anatomical deformities and exposure to environmental stress (for the detailed overview of etiology and pathology see Fjelldal et al., 2012). However, other studies demonstrated the genetic basis of the developmental deformities not only in the genus Salvelinus (Morita and Yamamoto, 2000; Sato,
2006) and other fish (Shikano et al. 2005, 2008; Chin et al., 2016) but in other animals as well, such as mammals (Roelke et al., 1993), reptiles (Madsen et al., 1996) and amphibians (Chen et al., 2016). In these studies, developmental deformities were concomitant with the low genetic diversity and inbreeding depression. The results of our study are congruent with such findings. In all three investigated broodstocks only one mtDNA haplotype was detected. According to Bernatchez and Danzmann (1993), the variations present in the investigated segment are representative of those over the entire mitochondrial genome of the brook trout and therefore sufficient for determining the haplotype. Observed low transition/ transversion ratio (2:1) can be found not only in the D-loop region of salmonids (Bernatchez et al., 1992; Bernatchez and Danzmann, 1993) but also in other teleost fish (Fajen and Breden, 1992; Kim et al., 2010; Kalamujić Stroil et al., 2019).

Sfo markers were the first markers used for analyzing species of the genus Salvelinus (Angers et al., 1995). However, along with Ssa-85 and Ssa-197, they proved to be useful for the investigation of other salmonids as well (Angers and Bernatchez, 1997; Gross et al., 2004; Palermo et al., 2012). Observed alleles are within the ranges described in previous studies (Angers et al., 1995; Angers and Bernatchez, 1996; Adams and Hutchings, 2003; Blanchfield et al., 2003; Fopp-Bayat et al., 2010). However, across all loci, the number of alleles and genotypes was low. Except for some loci in DJA brood, the allele count per locus was four or less, which is in concordance with the findings of Beer et al. (2019) who examined the genetic diversity of three brook trout strains in two hatcheries in New York State, USA. Just as population bottleneck is inevitable when establishing the breeding stock, genetic drift and population size fluctuation are likely to follow. The results of iMAF analysis in our study point out to the fact that the allele with the highest frequency has a tendency to increase its frequency, which might result in the depletion of other alleles with lower frequencies (Pojskić, 2018). Loss of rare alleles and fixation of the most frequent ones are common results (Allendorf, 1986; Frankham et al., 2002). The largest number of unique alleles was found in DJA broodstock which can probably be accounted for the most recent establishment of this hatchery among the surveyed ones. Due to the low number of generations since its establishment until the analyses, loss of rare alleles was not severe.

In our study, detected inbreeding coefficient was very prominent, both in the total sample and individual broods, while the gene diversity and observed heterozygosity had low rates. Extreme inbreeding is expected in hatcheries as they are typical examples of small isolated populations that are, in addition, under significant anthropogenic influence (selection). A similar observation was made in a study by Fopp-Bayat et al. (2010) where genetic diversity of wild and farmed populations of $S$. fontinalis was compared. 
Marked dominance of identical alleles per locus in the analyzed stocks and, to some extent, results of FCA possibly point to their common origin, but translocation of fish between observed fish farms cannot be excluded as well. However, the common practice of utilizing the same broodstock for spawning purposes for multiple generations, without introducing new, unrelated individuals, resulted in inbreeding depression which explains the observed differentiation between stocks. Since farmers did not report recent outbreaks of infectious disease or exposure to any evident environmental stress in the hatcheries, genetic factor (manifested in low genetic diversity and high inbreeding in broodstocks) cannot be excluded as a possible cause for the developmental deformities in smolts and fingerlings.

Material from these hatcheries has been used for stocking of the River Neretva for over a decade. However, these stocking efforts proved to be futile as no findings of sustainable population of brook trout in the wild have been reported in this millennium. Previous studies showed that in natural environments, farmed brook trout tended to exhibit lower survival rates (Fraser, 1981; Beer et al., 2019) and lower reproductive abilities (Araki et al., 2007, 2008). On the other hand, this is beneficial for the native fish community as alien species can pose a threat to the autochthonous and endemic gene pool either through hybridization, competition for habitat and food or direct predation.

In conclusion, the development of dorsal and fin deformities are shortcomings of intensive farming of inbred fish. Therefore, regular supplementation of broodstock with new, unrelated individuals are of vital importance for sustaining a satisfying level of genetic diversity and preventing inbreeding depression. Additionally, maintaining good management practices regarding the fluctuation of water temperature, exposure to pollution, nutrition, etc., will further contribute to the prevention of this detrimental condition.

\section{ACKNOWLEDGMENTS}

The authors would like to express their gratitude to prof. dr. Rifat Škrijelj for his indispensable help in organizing the sampling trips as well as to the hatcheries' owners for the permission to collect samples used in this study.
SAŽETAK

\section{GENETIČKE KARAKTERISTIKE MATIČNIH JATA POTOČNE ZLATOVČICE (Salvelinus fontinalis MITCHILL, 1848) IZ RIBOGOJILIŠTA U BOSNI I HERCEGOVINI}

Najčešće uzgajane riblje vrste u Bosni i Hercegovini su iz porodice Salmonidae, uključujući i potočnu zlatovčicu (Salvelinus fontinalis) koju se uzgaja za prehranu i za potrebe poribljavanja. Na uzgajalištima je primjećena povećana učestalost anatomskih deformacija kod mlađi potočne zlatovčice koje uzrokuju smanjenje kondicije kod riba, a time i značajne financijske gubitke. S obzirom da je dokazano da je pojava deformacija u korelaciji s niskom genetičkom raznolikošću i visokom stopom uzgoja u srodstvu, ova studija je imala za cilj procijeniti unutar i međupopulacijsku raznolikost Salvelinus fontinalis iz različitih ribogojilišta u Bosni i Hercegovini na osnovu varijacija mitohondrijskog i nuklearnog genoma. Primjenom mitohondrijskog kontrolnog područja i sedam nuklearnih mikrosatelitnih lokusa analizirano je ukupno 109 uzoraka potočne zlatovčice iz tri ribogojilišta locirana na rijeci Neretvi. Metoda PCR-RFLP i metoda sekvenciranja pokazale su samo jedan haplotip kontrolnog područja u svim istraživanim jedinkama. Uočen je mali broj genotipova za sve promatrane mikrosatelitne lokuse. Vrijednost genetičke raznolikosti i sadržaj informativnog polimorfizma pratili su porast u broju alela po lokusu. Općenito, vrijednost koeficijenta uzgoja u srodstvu bio je generalno veoma visok, dok su genetska raznolikost i uočena heterozigotnost imali niske stope. Rezultati provedene studije usuglasnostisu s rezultatima prethodnih istraživanja u kojima su razvojne deformacije bile praćene niskom genetičkom raznolikošću i inbreeding depresijom. Stoga se posebno preporuča redovno nadopunjavanje matičnog jata novim, nesrodnim jedinkama s obzirom da je to od presudnog značaja za održanje zadovoljavajuće razine genetičke raznolikosti i sprečavanje inbreeding depresije. Također, održavanje dobre prakse upravljanja u pogledu fluktuacije temperature vode, izloženosti zagađenju, prehrane itd. će dodatno prevenirati nastanak ovog štetnog stanja.

Ključne riječi: uzgoj u srodstvu, razvojne deformacije, mikrosateliti, mitohondrijska DNK

\section{REFERENCES}

Adams, B. K., Hutchings, J. A. (2003): Microgeographic population structure of brook charr: a comparison of microsatellite and mark-recapture data. Journal of Fish Biology, 62, 517-533. 
Allendorf, F. W. (1986): Genetic drift and the loss of alleles versus heterozygosity. Zoo Biology, 5, 181-190.

Angers, B., Bernatchez, L., Angers, A., Desgroseillers, L. (1995): Specific microsatellite loci for brook charr reveal strong population subdivision on a microgeographic scale. Journal of Fish Biology, 47, Supplement A, 177185.

Angers, B., Bernatchez, L. (1996): Usefulness of heterologous microsatellites obtained from brook charr, Salvelinus fontinalis Mitchill, in other Salvelinus species. Molecular Ecology, 5, 317-319.

Angers, B., Bernatchez, L. (1997): Complex evolution of a salmonid microsatellite locus and its consequence in inferring allelic divergence from size information. Molecular Biology and Evolution, 14, 3, 230-238.

Araki, H., Cooper, B., Blouin, M. S. (2007): Genetic effects of captive breeding cause a rapid, cumulative fitness decline in the wild. Science, 318, 5847, 100-103.

Araki, H., Berejikian, B. A., Ford, M. J., Blouin, M. S. (2008): Fitness of hatchery-reared salmonids in the wild. Evolutionary Applications, 1, 2, 342-355.

Beer, S. D., Cornett, S., Austerman, P., Trometer, B., Hoffman, T., Bartron, M. L. (2019): Genetic diversity, admixture, and hatchery influence in Brook Trout (Salvelinus fontinalis) throughout western New York State. Ecology and Evolution, doi.org/10.1002/ ece3.5237.

Behnke, R. J. (2002): Trout and salmon of North America. New York (NY), The Free Press.

Belkhir K, Borsa P, Chikhi L, Raufaste N, Bonhomme F (1996-2004): GENETIX 4.05, logiciel sous Windows TM pour la génétique des populations. Laboratoire Génome, Populations, Interactions, CNRS UMR 5000, Université de Montpellier II,Montpellier (France).

Benson, D. A., Karsch-Mizrachi, I., Lipman, D. J., Ostell, J., Wheeler, D. L. (2003): GenBank. Nucleic Acids Research, 31, 23-27.

Bernatchez, L., Gyuomard, L. R., Bonhome, F. (1992): Sequence variation of the mitochondrial control region among geographically and morphologically remote European brown trout (Salmo trutta L.) populations. Molecular Ecology, 1, 161-173.

Bernatchez, L., Danzmann, R. G. (1993): Congruence in control-region sequence and restriction-site variation in mitochondrial DNA of brook charr (Salvelinus fontinalis Mitchill). Molecular Biology and Evolution, 10, 1002-1014.

Blanchfield, P. J., Ridgway, M. S., Wilson, C. C. (2003): Breeding success of male brook trout (Salvelinus fontinalis) in the wild. Molecular Ecology, 12, 24172428.

Brody, J. R., Kern, S. E. (2005): Sodium boric acid: a Tris - free, cooler conductive medium for DNA electrophoresis. Biotechniques, 38, 1, 60.
Bruce, S. A., Daniel P. C., Krause, M. K., Henson, F. G., Pershyn, C. E., Wright, J. J. (2019): A methodological approach to the genetic identification of native Brook Trout (Salvelinus fontinalis) populations for conservation purposes. Global Ecology and Conservation, 19, e00682.

Brudford, M. W., Wayne, R. K. (1993): Microsatellites and their application to population genetic studies. Current Opinion in Genetics \& Development, 3, 939-943.

Brunner, P. C., Douglas, M. R., Bernatchez, L. (1998): Microsatellite and mitochondrial DNA assessment of population structure and stocking effects in Arctic charr Salvelinus alpinus (Teleostei: Salmonidae) from central Alpine lakes. Molecular Ecology, 7, 209-223.

Chen, S-Y., Zhang, Y-J., Wang, X-L., Sun, J-Y., Xue, Y., Zhang, P., et al. (2012): Extremely Low Genetic Diversity Indicating the Endangered Status of Ranodon sibiricus (Amphibia: Caudata) and Implications for Phylogeography. PLoS ONE 7(3): e33378.

Chin, H. N., Loh, R., Hong, Y. C., Gibson-Kueh, S. (2016): Case studies of spinal deformities in ornamental koi, Cyprinus carpio L. Journal of Fish Diseases, 40, 1, 65-71.

Durmić-Pašić, A., Pojskić, N., Kalamujić, B., Hadžiselimović, R. (2005): Genetic characterization of fish populations and its use in landscape conservation in Bosnia and Herzegovina. International workshop "The role of biotechnology for the characterization and conservation of crop, forestry, animal and fishery genetic resources". 2005, Mar 5-7, Turin, Italy. Book of proceedings, 173-174.

Fajen, A., Breden, F. (1992): Mitochondrial NDA sequence variation among natural populations of the Trinidad guppy, Poecilia reticulata. Evolution, 46, 1457-1465.

Ferguson-Castle Douglas, A. (2006): Genetic impacts of stocking on indigenous brown trout populations. Bristol (UK), Rio House. 20pp.

Fjelldal, P. G., Hansen, T., Breck, O., Ørnsrud, R., Lock, E.-J., Waagb $\varnothing$, R., Wargelius, A., Eckhard Witten, P. (2012): Vertebral deformities in farmed Atlantic salmon (Salmo salar L.) - etiology and pathology. Journal of Applied Ichthyology, 28, 433-440.

Food and Agricultural Organization of the United Nations (FAO) (2015): The Fisheries and Aquaculture Sector in Bosnia and Herzegovina - Preparations of IPARD Forest and Fisheries Sector Review in Bosnia and Herzegovina. FAO Regional Office for Europe and Central Asia.

Fopp-Bayat, D., Jankun, M., Kuzminski, H. (2010): Genetic characterization of Polish cultured brook trout, Salvelinus fontinalis (Mitchill), based on microsatellite DNA analysis. Archives of Polish Fisheries, 18, 93-99.

Frankham, R., Ballou, J. D., Briscoe, D. A. (2002): Introduction to Conservation Genetics. Cambridge: Cambridge University Press.

Fraser, J. (1981): Comparative survival and growth of 
planted wild, hybrid, and domestic strains of Brook Trout (Salvelinus fontinalis) in Ontario lakes. Canadian Journal of Fisheries and Aquatic Sciences, 38, 12, 16721684.

Gross, R., Gum. B, Reiter, R., Kühn, R. (2004): Genetic introgression between Arctic charr (Salvelinus alpinus) and brook trout (Salvelinus fontinalis) in Bavarian hatchery stocks inferred from nuclear and mitochondrial DNA markers. Aquaculture International, 12, 19-32.

Hall, T. A. (1999): BIOEDIT: a user-friendly biological sequence alignment editor and analysis program for Windows 95/98/NT. Nucleic Acids Symposium Series, 41, 95-98.

Kalamujić Stroil, B., Dorić, S., Hanjalić, J., Lasić, L., Pojskić, N. (2017): Regional biodiversity database (REBIDA) the first comprehensive database of biological diversity of Bosnia and Herzegovina. Genetics \& Applications, 1, 2, 59-65.

Kalamujić Stroil, B., Mušović, A., Škrijelj, R., Dorić, S., Đug, S., Pojskić, N. (2019): Molecular-genetic diversity of the endangered Dalmatian barbelgudgeon, Aulopyge huegelii from the Buško Blato reservoir. Genetica, 1-12, doi.org/10.1007/s10709-019-00069-z.

Kim, J. K., Kim, Y. H., Kim, M-J., Park, J. Y. (2010): Genetic diversity, relationships and demographic history of the small yellow croaker, Larimichthys polyactis (Pisces: Sciaenidae) from Korea and China inferred from mitochondrial control region sequence data. Animal Cells and Systems, 14, 45-51.

Kosoric, D. (1981): Fish populations of river Krivaja. Excerpt from the yearbook of the Biological Institute, 34, 57-72.

Lacy, R. C. (1989): Analysis of founder representation in pedigrees: founder equivalents and founder genome equivalents. Zoo Biology, 8, 111-123.

Liu, K., Muse, S. V. (2005): PowerMarker: an integrated analysis environment for genetic marker analysis. Bioinformatics, 21, 2128-2129.

Miller, S. A., Dykes, D. D., Polesky, H. F. (1988): A simple salting-out procedure for extracting DNA from human nucleated cells. Nucleic Acids Research, 16, 1215.

Morita, K., Yamamoto, S. (2000): Occurrence of deformed whitespotted charr, Salvelinus leucomaenis (Pallas), population on the edge of its distribution. Fisheries Management and Ecology, 7, 551-553.

Muhamedagic, S., Gjoen, H. M., Vegra, M. (2008): Salmonids of the Neretva river basin - present state and suggested sustainable selection programme to protect and strengthen salmonid populations. In: EIFAC FAO Fisheries and Aqauculture, editor. The Symposium on Interactions between Social, Economic and Ecological Objectives of Inland Commercial and Recreational Fisheries and Aquaculture; 2008, 21. - 24. May, Antalya, Turkey, Ministry of Agriculture and Rural
Affairs of Turkey. p. 224-232.

Nei, M., Maruyama, T., Chakraborty, R. (1975): The bottleneck effect and genetic variability of populations. Evolution, 29, 1-10.

O'Reilly, P. T., Hamilton, L. C., McConnell, S. K., Wright, J. M. (1996): Rapid analysis of genetic variation in Atlantic salmon (Salmo salar) by PCR multiplexing of dinucleotide and tetranucleotide microsatellites. Canadian Journal of Fisheries and Aquatic Sciences, 53, 2292-2298.

Palermo, M., Latourelle, S., Elwess, N. L. (2012): Genetic analysis of the brown, brook and tiger trout populations in the Lake Champlain basin. The Journal of Experimental Secondary Science, 2, 1, 40-43.

Pearson, W.R. (1994): Using the FASTA program to search protein and DNA sequence databases. Methods in Molecular Biology, 24, 307-331.

Pojskić, N. (2018): iMAF - Index of Major Allele Frequency. Genetics \& Applications, 2, 2, 78-81.

Sato, T. (2006): Occurrence of Deformed Fish and Their Fitness-related Traits in Kirikuchi Charr, Salvelinus leucomaenis japonicus, the Southernmost Population of the Genus Salvelinus. Zoological Sciences, 23, 593599.

Shikano, T., Ando, D., Taniguchi, N. (2005): Relationships of vertebral deformity with genetic variation and heterosis in the guppy Poecilia reticulate. Aquaculture, 246, 133-138.

Shikano, T., Shimada, Y., Suzuki, H. (2008): Comparison of genetic diversity at microsatellite loci and quantitative traits in hatchery populations of Japanese flounder Paralichthys olivaceus. Journal of Fish Biology, 72, 386399.

Silverstone, A. M., Hammell, L. (2002): Spinal deformities in farmed Atlantic salmon. The Canadian Veterinary Journal, 43, 10, 782-784.

Snoj, A., Sušnik, S., Pohar, J., Dovc, P. (1999): The first microsatellite marker (BFRO 004) for grayling, informative for its Adriatic population. Animal Genetics, 30, 74-75.

Snoj, A., Jug, T., Melkic, E., Susnik, S., Pohar, J., Dovc, P., Jesensek, D., Budihna, N. (2000): Mitochondrial and microsatellite DNA analysis of marble trout in Slovenia. Journal of Freshwater Biology, 29, 5-11.

Sullivan, M., Guy, D. R., Roberts, R. J., Manchester, N. J. (2007): The aetiology of spinal deformity in Atlantic salmon, Salmo salar L.: influence of genetic factors on the frequency and severity in freshwater stages. Journal of Fish Disease, 30, 753-758.

Thompson, J. D., Higgins, D. G., Gibson, T. J. (2011): CLUSTAL W: improving the sensitivity of progressive multiple sequence alignment through sequence weighting, positions-speciWc gap penalties and weight matrix choice. Nucleic Acids Research, 22, 4673-4680. 
Van Oosterhout, C., Hutchinson, W. F., Wills, D., Shipley, P. (2004): MICRO-CHECKER: Software for identifying and correcting genotyping errors in microsatellite data. Molecular Ecology Notes, 4, 535-538.
Waterhouse, A. M., Procter, J. B., Martin, D. M. A., Clamp, M., Barton, G. J. (2009): Jalview Version 2-a multiple sequence alignment editor and analysis workbench. Bioinformatics, 25, 1189-1191. 